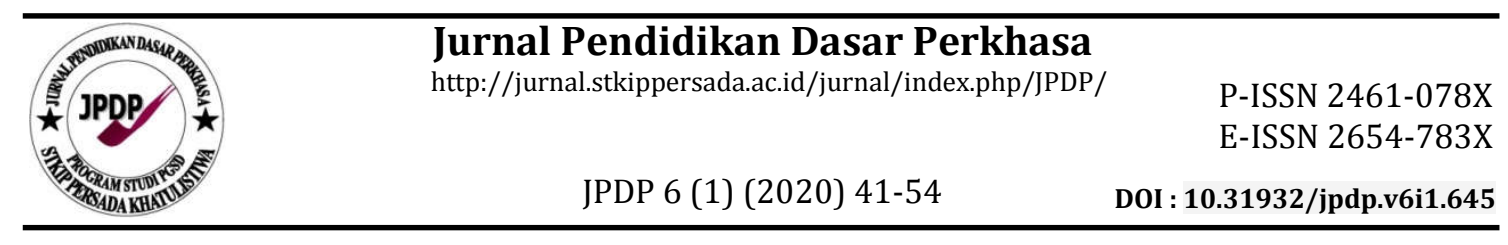

\title{
MODEL MIND MAPPING PADA PEMBELAJARAN TEMATIK KELAS IV SISWA SEKOLAH DASAR
}

\author{
Rizky Novioleta $^{* 1}$, Nelly Wedyawati ${ }^{2}$, Agusta Kurniati ${ }^{3}$ \\ 1,2,3Program Studi PGSD, STKIP Persada Khatulistiwa \\ Diterima: 26 Februari 2020. Dipublikasi: 21 April 2020.
}

\begin{abstract}
In general, the purpose of this study was to determine the application of mind mapping models for class IV of Nanga Tikan State Elementary School 09. Research uses a qualitative approach to classroom action research. Performed in two cycles. As for the subjects in the study were 8th grade students with a total of 8 students and 1 teacher. Data collection techniques in this study are direct observation techniques, tests, questionnaire techniques, and interview techniques while the data collection tools used are observation sheets of students, teachers, cognitive test questions, affective assessment sheets, psychomotor and student response questionnaire. The results obtained by applying the mind mapping model of teacher activity evaluation $80 \%$ in cycle I $100 \%$ in cycle II. Assessment of learning activities for students in cycle I $80 \%$ in cycle II $100 \%$. Cognitive learning outcomes of students using the mind mapping model increased from cycle I $73.75 \%$ to $92.63 \%$ in the second cycle an increase of $18.88 \%$. The increase in affective learning outcomes of students in the first cycle $73 \%$ in the second cycle $90 \%$ there was an increase in the affective assessment of students by $17 \%$. The increase in psychomotor learning outcomes of students in the first cycle was $52 \%$ and in the second cycle was $92 \%$ an increase of $40 \%$. Questionnaire student responses to the use of mind mapping models in the first cycle $76 \%$ with category B and cycle II increased to $98 \%$ with category A. It can be concluded in general that the use of mind mapping models can be improvedlearning outcomes.
\end{abstract}

Keywords: Mind Mapping, Teaching, Tematic, Student, Elementary School

Abstrak. Secara umum tujuan penelitian untuk mengetahui penerapan model mind mapping kelas IV Sekolah Dasar Negeri 09 Nanga Tikan. Penelitian menggunakan pendekatan kualitatif bentuk penelitian tindakan kelas. Dilaksanakan sebanyak dua siklus. Adapun yang menjadi subjek dalam penelitian adalah siswa kelas IV dengan jumlah 8 siswa dan 1 orang guru. Teknik pengumpulan data dalam penelitian yaitu teknik observasi langsung, tes, teknik kuesioner, dan teknik wawancara sedangkan alat pengumpulan data yang digunakan yaitu lembar observasi siswa, guru, soal tes kognitif, lembar penilaian afektif, psikomotor dan angket respon siswa. Hasil yang diperoleh penerapan model mind mapping penilaian aktivitas guru siklus I $80 \%$ siklus II $100 \%$. Penilaian aktivitas belajar siswa siklus I $80 \%$ siklus II $100 \%$. Hasil belajar kognitif siswa menggunakan model mind mapping mengalami peningkatan dari siklus I 73,75\% siklus II 92,63\% terjadi peningkatan sebesar 18,88\%. Peningkatan hasil belajar afektif siswa siklus I $73 \%$ siklus II $90 \%$ terjadi peningkatan pada penilaian afektif siswa sebesar $17 \%$. Peningkatan hasil belajar psikomotor siswa siklus I 52\% dan siklus II sebesar 92\% terjadi peningkatan sebesar $40 \%$. Angket respon siswa terhadap penggunaan model mind mapping pada siklus I 76\% dengan kategori B dan siklus II mengalami peningkatan menjadi $98 \%$ dengan kategori A. Kesimpulan umum bahwa pembelajaran mind mapping meningkatkan hasil belajar siswa kelas IV Sekolah Dasar.

Kata kunci: Mind Mapping, Pembelajaran, Tematik, Siswa, SD 
R. Novioleta, N. Wedyawati, A. Kurniati | JPDP 6 (1) April 2020, 41-54

Pendahuluan

Pendidikan

merupakan

rangkaian dari keseluruhan proses pembelajaran yang di dalamnya terdapat suatu aktivitas belajar dan pembelajaran yang dilakukan oleh siswa dan guru yang bertujuan untuk memperoleh ilmu pengetahuan. Dengan adanya pendidikan yang terjadi disekolah diharapkan dapat membawa sebuah perubahan dari tidak tahu menjadi tahu hal-hal yang belum dipelajari oleh siswa sebelumnya. Proses belajar siswa dipengaruhi oleh banyak faktor. Menurut (Slameto, 2015) "Faktorfaktor yang mempengaruhi belajar banyak jenisnya, tetapi dapat digolongkan menjadi dua golongan saja, yaitu faktor intern dan faktor ekstern. Faktor intern adalah faktor yang ada dalam diri individu yang sedang belajar, sedangkan faktor ekstern adalah faktor yang ada di luar individu. Oleh karena itu, para pendidik, pembimbing, dan pengajar di dalam mengatur dan mengendalikan faktor-faktor yang mempengaruhi belajar mengajar sehingga proses belajar mengajar berjalan dengan optimal.

*surel korespondensi: novioleta111@gmail.com
Berdasarkan hasil praobservasi peneliti di Sekolah Dasar Negeri 09 Nanga Tikan di kelas IV ditemukan bahwa dalam proses pembelajaran di kelas siswa cenderung tidak aktif, asik bermain dengan teman sebangkunya, mengantuk di kelas, malas mencatat materi pelajaran, bosan, melamun, sulit memahami penjelasan guru dan guru yang menggunakan model dalam pembelajaran kurang bervariasi, guru kelas masih menggunakan metode ceramah sehingga hanya guru yang aktif sementara siswa tidak semua yang berperan aktif saat proses pembelajaran sehingga berdampak pada hasil belajar siswa beberapa menjadi rendah.

Menurut (Amri, 2013), "Model pembelajaran adalah sebagai suatu desain yang menggambarkan proses rincian dan penciptaan situasi lingkungan yang memungkinkan siswa berinteraksi sehingga terjadi perubahan atau perkembangkan pada diri siswa." Suasana kelas IV di Sekolah Dasar Negeri 09 Nanga Tikan perlu direncanakan dan dibangun sedemikian rupa dengan menggunakan model pembelajaran yang tepat agar siswa dapat meemperoleh kesempatan untuk 
R. Novioleta, N. Wedyawati, A. Kurniati | JPDP 6 (1) April 2020, 41-54

berinteraksi satu sama lain sehingga pada gilirannya dapat diperoleh hasil belajar yang optimal.

Berdasarkan uraian dari pemikiran peneliti yang telah dipaparkan maka peneliti ingin melakukan penelitian yang berjudul "Penerapan Model Mind Mapping Pada Tema Selalu Berhemat Energi Subtema Sumber Energi Kelas IV Sekolah Dasar Negeri 09 Nanga Tikan Tahun Pelajaran 2019/2020". Harapan peneliti dengan penerapan Model Mind Mapping ini dapat meningkatkan hasil belajar siswa di kelas IV SDN 09 Nanga Tikan.

Menurut Awang (2017), "Belajar merupakan sebuah aktivitas sadar yang dilakukan oleh seseorang. Tidak ada orang belajar diluar kesadaran." Selanjutnya menurut Sadirman (Zarkasih, dkk., 2016) menyatakan bahwa "Belajar adalah berubah, dalam hal ini yang dimaksudkan belajar berarti usaha mengubah tingkah laku". Belajar itu sendiri akan menunjukkan adanya perubahan sehingga pada tahap akhir akan didapat keterampilan, kecakapan, dan pengetahuan baru. Menurut (Susanto, 2016) hasil belajar adalah perubahanperubahan yang terjadi pada diri siswa, baik yang menyangkut aspek kognitif, afektif, dan psikomotor sebagai hasil dari kegiatan belajar. Menurut (Sudjana, 2016) "Ranah kognitif berkenaan dengan hasil belajar intelektual yang terdiri dari enaam apek yakni pengetahuan atau ingatan, pemahaman, aplikasi, analisis, sintesis, dan evaluasi." Hasil belajar afektif adalah kemampuan yang berhubungan dengan sikap, nilai, minat, dan apresiasi. Menurut (Sudjana, 2016) "Hasil belajar psikomotoris tampak dalam bentuk keterampilan (skill) dan kemampuan bertindak individu." Terdapat lima tahapan dalam ranah psikomotor mulai dari tingkat yang sederhana hingga tingkat yang rumit menurut Dave dalam (Majid, 2017). Menurut (Buzan, 2012)Mind mapping adalah cara termudah untuk menempatkan informasi ke dalam otak dan mengambil informasi ke luar dari otak. Mind mapping adalah cara mencatat yang kreatif, efektif, dan secara harafiah akan "memetakan" pikiran-pikiran kita. Mind mapping juga sangat sederhana. Menurut Silberman (Shoimin, 2014), "Mind mapping atau pemetaan pikiran merupakan cara kreatif bagi tiap 
R. Novioleta, N. Wedyawati, A. Kurniati | JPDP 6 (1) April 2020, 41-54

pembelajaran untuk menghasilkan gagasan, mencatat apa yang dipelajari, atau merencanakan tugas baru." Menurut (Shoimin, 2014) langkahlangkah model mind mapping adalah sebagai berikut:

1. Guru menyampaikan tujuan pembelajaran yang ingin dicapai.

2. Guru menyajikan materi sebagaimana biasa.

3. Siswa dibagi kedalam beberapa kelompok yang anggotanya 2 orang.

4. Siswa merancang peta pikiran.

5. Siswa mempresentasekan hasil diskusi secara berkelompok.

6. Guru mengulangi atau menjelaskan kembali materi sekiranya belum dipahami siswa.

7. Kesimpulan atau penutup.

\section{Metode}

Pendekatan penelitian ini menggunakan pendekatan penelitian kualitatif. Menurut Sugiyono (2016), "Metode penelitian kualitatif itu dilakukan secara intensif, peneliti ikut berpartisipasi lama di lapangan, mencatat secara hati-hati apa yang terjadi, melakukan analisis refleksi terhadap berbagai dokumen yang ditemukan dilapangan, dan membuat laporan penelitian secara mendetail." Teknik yang digunakan dalam penelitian ini adalah model mind mapping. Penelitian kualitatif digunakan untuk mendeskripsikan Penerapan Model Mind Mapping pada Tema Selalu Berhemat Energi Subtema Sumber Energi Kelas IV Sekolah Dasar Negeri 09 Nanga Tikan Tahun 2019/2020.

Sugiyono (2016) menuliskan, "Metode penelitian pada dasarnya merupakan cara ilmiah untuk mendapatkan data dengan tujuan dan kegunaan tertentu". Metode penelitian yang digunakan dalam penelitian ini adalah metode penelitian deskriptif karena dijabarkan dalam bentuk katakata. Peneliti memilih metode deskriptif karena dalam penelitian ini peneliti mendeskripsikan keadaan mengenai peningkatan hasil belajar kognitif, afektif dan psikomotor siswa. Bentuk penelitian ini merupakan bentuk penelitian tindakan kelas (classroom action research). Bentuk penelitian tindakan kelas (PTK) menurut Kunandar (2016), “PTK adalah penelitian tindakan yang dilakukan dengan tujuan memperbaiki mutu praktik pembelajaran di kelas." Penelitian di lakukan dikelas IV 
R. Novioleta, N. Wedyawati, A. Kurniati | JPDP 6 (1) April 2020, 41-54

Sekolah Dasar Negeri 09 Nanga Tikan, dimana penelitian ini terjadi secara kolektif dalam suatu proses pembelajaran untuk melakukan evaluasi terhadap suatu metode pembelajaran yang digunakan. Penelitian ini lebih memfokuskan pada upaya guru meningkatkan hasil bejar kognitif, afektif dan pikomotor siswa dikelas IV Sekolah Dasar Negeri 09 Nanga Tikan dengan menggunakan model mind mapping pada tema selalu berhemat energi subtema sumber energi.

Dalam penelitian ini peneliti mengambil subjek penelitian pada siswa kelas IV sekolah dasar Negeri 09 Nanga Tikan tahun pelajaran 2019/2020. Jumlah siswa adalah 8 orang siswa, dengan rincian 3 orang siswa perempuan dan 5 orang siswa laki-laki. Pada penelitian tindakan kelas ini, objek dalam penelitian ini adalah mengenai penggunaan model pembelajaran mind mapping dalam meningkatkan hasil belajar siswa pada tema selalu berhemat energi subtema sumber energi kelas IV Sekolah Dasar Negeri 09 Nanga Tikan. Arikunto (2015) menyatakan, "Hal yang dimaksud dengan setting atau latar penelitian adalah keadaan lokasi tempat penelitian berlangsung, meliputi situasi fisik, keadaan siswa, suasana, serta hal-hal lain yang banyak berpengaruh terhadap tindakan yang dilakukan oleh guru ketika penelitian tindakan berlangsung". Penelitian ini dilakukan didalam kelas IV SDN 09 Nanga Tikan. Penelitian dilakukan saat proses pembelajaran tematik. Tempat penelitian ini adalah di Sekolah dasar Negeri 09 Nanga Tikan yang terletak di Desa Nanga Tikan Kecamatan Belimbing Hulu Kabupaten Melawi, Provinsi Kalimantan Barat. Untuk memperoleh secara obyektif guna memecahkan masalah dalam penelitian ini, maka teknik pengumpulan data yang tepat agar data yang digunakan dapat di pertanggung jawabkan. (Sugiyono, 2016) mengemukakan pengumpulan data dapat dilakukan dalam berbagai setting, berbagai sumber, dan berbagai cara. Teknik pengumpulan data dalam penelitian ini yaitu teknik observasi langsung, tes, teknik kuesioner (angket) dan tenik wawancara. Teknik obervasi langsung digunakan untuk melihat aktivitas belajar guru dan siswa, penilaian afektif dan psikomotor, teknik tes 
R. Novioleta, N. Wedyawati, A. Kurniati | JPDP 6 (1) April 2020, 41-54

digunakan untuk melihat hasil belajar lalu dibagi 3 dapatlah hasil kognitf siswa, teknik kuesioner kemampuan guru menggunakan (angket) digunakan untuk meilhat model mind mapping siklus I yaitu repon siswa, dan teknik wawancara $63 \%$ dengan tingkat pencapaian digunakan untuk melihat respon guru berada pada kategori C (cukup). terhadap model pembelajarn mind Observai guru siklus II pertemuan ke I mapping.

\section{Hasil dan Pembahasan}

Hasil

Hasil dari observasi guru menggunakan model mind mapping pada siklus I pertemuan ke-I 50\%, pertemuan ke-II $60 \%$ dan pertemuan ke-III 80\% maka hitungan akhir siklus I yaitu tiga pertemuan ditambahkan $100 \%$, pertemuan ke II 100\%, pertemuan ke III 100\% maka hitungan akhir siklus II yaitu tiga pertemuan ditambahkan lalu dibagi 3 dapatlah hasil kemampuan guru menggunakan model mind mapping siklus II yaitu 100\% dengan tingkat pencapaian berada pada kategori A (sangat baik).

\begin{tabular}{ccc}
\multicolumn{2}{c}{ Tabel 1. Hasil Observasi Aktivitas Guru } \\
\hline No & Observasi Guru & Skor (\%) \\
\hline 1 & Pertemuan I & 50 \\
2 & Pertemuan II & 60 \\
3 & Pertemuan III & 80 \\
4 & Pertemuan IV & 100 \\
5 & Pertemuan V & 100 \\
6 & Pertemuan VI & 100 \\
\hline
\end{tabular}

Hasil dari observasi aktivitas siswa siklus I pada pertemuan ke I yaitu 50\%, pertemuan ke II yaitu 60\% dan pertemuan ke III yaitu $80 \%$ maka hitungan akhir pada siklus II yaitu tiga pertemuan ditambahkan lalu dibagi 3 dapatlah hasil aktivitas belajar siswa yaitu 63\% dengan tingkat pencapaian berada pada kategori C (cukup). Observasi siswa siklus II pertemuan ke I $100 \%$, pertemuan ke II 100\%, pertemuan ke III 100\% maka hitungan akhir siklus II yaitu tiga pertemuan ditambahkan lalu dibagi 3 dapatlah hasil aktivitas belajar siswa menggunakan model mind mapping siklus II yaitu 100\% dengan tingkat pencapaian berada pada kategori A (sangat baik). 


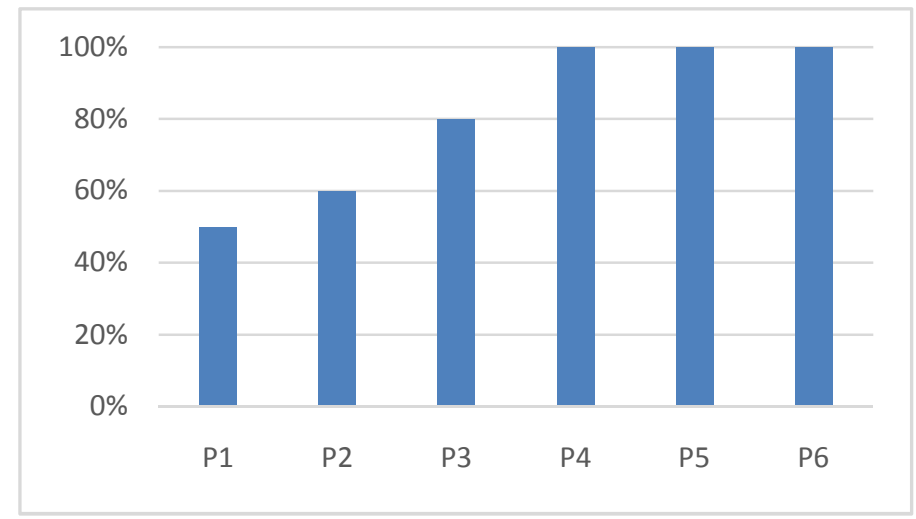

Gambar 1. Hasil Observasi Aktivitas Siswa

Hasil belajar siswa pada soal pilihan ganda siklus I terdapat 5 orang siswa yang tuntas dan 3 orang siswa yang tidak tuntas atau tidak memenuhi kriteria ketuntasan minimal. Nilai yang diperoleh pada siklus I dengan nilai tertinggi 90 dan nilai terendah 50 dengan rata-rata yaitu 72,50\%. Penilaian mind mapping siswa siklus I dengan 5 indikator penilaian, keterangan penilaian poin 5 sangat baik, poin 4 baik, poin 3 cukup, poin 2 kurang dan poin 1 sangat kurang. Penilaian mind mapping siswa dengan rata-rata nilai 75\%. Kemudian nilai pilihan ganda dan mind mapping siswa di tambah lalu dibagi dua maka dapatlah hasil belajar kognitif siswa siklus I.

\section{Tabel 2. Rekapitulasi Hasil Belajar Kognitif}

\begin{tabular}{ccc}
\hline No & Hasil Tes & Siklus I \\
\hline 1 & Nilai Tertinggi & 91 \\
2 & Nilai Terendah & 52 \\
3 & Tuntas & $62,50 \%$ \\
4 & Tidak Tuntas & $38 \%$ \\
5 & Nilai Rata-rata & $73,75 \%$ \\
6 & Ketuntasan Klasikal & $62,50 \%$ \\
\hline
\end{tabular}

Hasil belajar siswa pada soal pilihan ganda siklus II 8 orang siswa yang tuntas dan 0 orang siswa yang tidak. Nilai yang diperoleh pada siklus
II dengan nilai tertinggi 100 dan nilai terendah 80 dengan rata-rata yaitu 91,25\%. Penilaian mind mapping siswa siklus II dengan 5 indikator 


\section{R. Novioleta, N. Wedyawati, A. Kurniati | JPDP 6 (1) April 2020, 41-54}

penilaian, keterangan penilaian poin 5 mind mapping siswa di tambah lalu sangat baik, poin 4 baik, poin 3 cukup, dibagi dua maka dapatlah hasil belajar poin 2 kurang dan poin 1 sangat kognitif siswa siklus II. Adapun kurang. Penilaian mind mapping siswa rekapitulasi hasil belajar kognitif dengan rata-rata nilai $94,00 \%$. siklus II dapat dilihat pada Tabel 3. Kemudian nilai pilihan ganda dan

\section{Tabel 3. Rekapitulasi Hasil Belajar Kognitif}

\begin{tabular}{clc}
\hline No & \multicolumn{1}{c}{ Hasil Tes } & Siklus II \\
\hline 1 & Nilai Tertinggi & 100 \\
2 & Nilai Terendah & 84 \\
3 & Tuntas & $100 \%$ \\
4 & Tidak Tuntas & $0 \%$ \\
5 & Rata-Rata & $92,63 \%$ \\
6 & Ketuntasan Klasikal & $100 \%$ \\
\hline
\end{tabular}

Hasil penilaian afektif seperti pada Tabel 4., menunjukkan siswa pada siklus I pertemuan pertama yaitu $65 \%$, pertemuan kedua meningkat menjadi 73\%, pertemuan ketiga siklus I meningkat menjadi $81 \%$ secara keseluruhan afektif siswa siswa dikatakan baik karena kriteria penilaian afektif siswa sudah berada pada kategori B (baik). hasil penilaian afektif siswa kelas IV SDN 09 Nanga Tikan siklus II pada pertemuan pertama yaitu $80 \%$, pertemuan kedua meningkat menjadi $94 \%$ dan pertemuan ketiga siklus II yaitu 96\% jadi penilaian afektif siswa sudah berada pada kategori A (sangat baik), maka peneliti memutuskan untuk sampai pada siklus II mengigat pencapaikan sudah mencapai target.

Tabel 4. Skor Penilaian Afektif

\begin{tabular}{clccc}
\hline No & Hasil & Siklus I & Siklus II & Peningkatan \\
\hline 1 & P I & 65 & 80 & 15 \\
2 & P II & 73 & 94 & 21 \\
3 & P III & 81 & 96 & 15 \\
\hline Rata-rata & 73 & 90 & 17 \\
\hline
\end{tabular}

Hasil penilaian psikomotor siswa pada siklus I pertemuan pertama yaitu
39\%, pertemuan kedua meningkat menjadi 51\% dan pertemuan ketiga 
R. Novioleta, N. Wedyawati, A. Kurniati | JPDP 6 (1) April 2020, 41-54

yaitu 65\%. Hasil penilaian psikomotor meningkat menjadi 92\% dan siswa pada siklus II pertemuan pertemuan ketiga siklus II menjadi pertama yaitu 83\%, pertemuan kedua 100.

Tabel 5. Skor Penilaian Psikomotor

\begin{tabular}{clccc}
\hline No & Hasil & Siklus I & Siklus II & Peningkatan \\
\hline 1 & P I & 39 & 83 & 44 \\
2 & P II & 51 & 92 & 41 \\
3 & P III & 65 & 100 & 35 \\
\hline \multicolumn{2}{c}{ Rata-Rata } & 52 & 92 & 40 \\
\hline
\end{tabular}

Hasil angket respon siswa pada siklus I yang mendapatkan nilai dalam kategori B (baik) sebanyak 7 siswa dan yang mendapatkan nilai dalam kategori C (cukup) sebanyak 1 siswa jika di presentasikan secara keseluruhan yaitu 76\%. Pada siklus II angket respon siswa 8 siswa atau seluruh siswa sudah mendapatkan nilai dalam kategori A (sangat baik) jika di persentasikan secara keseluruhan yaitu 98\% jadi sudah berada pada kategori A (sangat baik).

Tabel 6. Peningkatan Hasil Angket Respon

\begin{tabular}{ccc}
\hline No & Hasil & Skor (\%) \\
\hline 1 & Siklus I & 76 \\
2 & Siklus II & 98 \\
\hline & Peningkatan & 22 \\
\hline
\end{tabular}

\section{Pembahasan}

Menurut Sudjana (Wedyawati \& Makin, 2019) Hasil belajar tampak sebagai terjadi perubahan tingkah laku pada diri siswa yang dapat diamati dan diukur dalam bentuk perubahan pengetahuan, sikap dan keterampilan. Menurut Susanto (2016) "Hasil belajar adalah perubahan-perubahan yang terjadi pada diri siswa, baik yang menyangkut aspek kognitif, afektif dan psikomotor sebagai hasil dari kegiatan belajar." Nilai hasil observasi guru menggunakan model mind mapping siklus I pertemuan pertama yaitu sebesar 50\% dengan kategori cukup, pada pertemuan kedua yaitu sebesar $60 \%$ kategori cukup dan pada 
R. Novioleta, N. Wedyawati, A. Kurniati | JPDP 6 (1) April 2020, 41-54

pertemuan ketiga yaitu sebesar $80 \%$ dengan kategori sangat baik. Maka peneliti melakukan evaluasi di akhir siklus dan perbaikan pada siklus II dengan hasil observasi guru menggunakan model mind mapping pada siklus II pertemuan pertama adalah $100 \%$, pertemuan kedua $100 \%$ dan pertemuan ketiga sebesar 100\% dengan kategori sangat baik. Hal ini berarti nilai hasil observasi guru menggunakan model mind mapping sudah memenuhi syarat.

Nilai hasil observasi siswa pada siklus I pertemuan pertama yaitu 50\% dengan kategori cukup, pertemuan kedua 60\% dengan kategori cukup dan pertemuan ketiga yaitu $80 \%$ dengan kategori sangat baik sedangkan hasil observasi siswa pada siklus II pertemuan pertama yaitu $100 \%$, pertemuan kedua 100\% dan pertemuan ketiga $100 \%$ dengan kategori sangat baik. Setelah dilakukan observasi guru menggunakan model mind mapping dan observasi aktivitas belajar siswa maka dapat disimpulkan bahwa penerapan model mind mapping sudah dinyatakan sangat baik karena guru sudah sangat baik dalam menerapkan model mind mapping dan aktivitas belajar siswa dengan penerapan model mind mapping sangat baik.

Penilaian hasil belajar kognitif siswa siklus I nilai rata-rata belajar siswa adalah 72,50\% dengan kategori baik (B) dengan jumlah nilai yang diperoleh 580, nilai tertinggi 90, nilai terendah 50, jumlah siswa yang tuntas pada siklus I ini yaitu 5 siswa atau $62,50 \%$ yang tuntas sedangkan jumlah siswa yang tidak tuntas yaitu 3 orang siswa atau 37,50\% dari 8 siswa kelas IV dan pada siklus II mengalami peningkatan dengan nilai rata-rata belajar siswa adalah 91,25\% kategori sangat baik (A) dengan jumlah nilai 730 , nilai tertinggi 100 , nilai terendah 80 , siswa yang tuntas yaitu sebanyak 8 orang siswa atau 100\% sedangkan yang tidak tuntas 0 atau $0 \%$ dari 8 siswa. Maka peningkatan nilai ratarata dari siklus I ke siklus II sebesar 18,75\%. Sedangkan penilaian mind mapping siswa pada siklus I dengan rata-rata nilai yaitu sebesar 75,00\% dengan kategori baik (B) dengan nilai tertinggi siswa pada siklus I ini yaitu sebesar 92 sedangkan nilai terendah siswa yaitu 44 dan pada siklus II mengalami peningkatan dengan ratarata yaitu sebesar 94,00\% dengan 
R. Novioleta, N. Wedyawati, A. Kurniati | JPDP 6 (1) April 2020, 41-54

kategori sangat baik (A) dengan nilai tertinggi siswa adalah 100 sedangkan nilai terendah siswa adalah 88 maka dapat disimpulkan bahwa peningkatan rata-rata mind mapping siswa dari siklus I ke siklus II sebesar 19,00\%. Mendapatkan nilai kognitif dari soal tes pilihan ganda sebanyak 10 soal dan mind mapping siswa maka peneliti menambahkan nilai soal tes pilihan ganda dengan nilai mind mapping yang di peroleh siswa lalu dibagi dua maka dapatlah hasil nilai kognitif siswa siklus I dengan ratarata yaitu sebesar $73,75 \%$ dengan kategori baik (B) dengan nilai tertinggi 91 sedangkan nilai terendah 52 dan mengalami peningkatan pada siklus II nilai rata-rata yaitu sebesar 92,62\% dengan kategori (A) dengan nilai tertinggi siswa yaitu 100 sedangkan nilai terendah yaitu 84, peningkatan rata-rata hasil belajar kognitif siwa yaitu 18,87\%.

Penilaian hasil belajar afektif siswa siklus I sampai siklus II mengalami peningkatan. siklus I pertemuan pertama yaitu sebesar 65\% dengan kategori cukup (C), siklus I pertemuan kedua sebesar $73 \%$ dengan kategori cukup (C) dan siklus I pertemuan ketiga sebesar 81\% dengan kategori sangat baik (A) penelitian dilanjutkan pada siklus ke II maka mendapatkan hasil pada siklus II yaitu mengalami peningkatan pertemuan I sebesar $80 \%$ dengan kategori sangat baik (A), siklus II pertemuan II yaitu sebesar 94\% dengan kategori sangat baik (A) dan siklus II pertemuan III yaitu sebesar 96\% dengan kategori sangat baik (A). maka peneliti memutuskan untuk sampai pada siklus ke II mengingat pencapaian hasil belajar afektid siswa kelas IV SD Negeri 09 Nanga Tikan sudah mencapai kriteria ketuntasan yang ditentukan.

Penilaian hasil belajar psikomotor siswa siklus I ke siklus II. Pada siklus I pertemuan pertama yaitu 39\% berada pada kategori kurang, pertemuan kedua yaitu sebesar 51\% berada pada kategori cukup dan pertemuan ketiga sebesar $65 \%$ berada pada kategori cukup dengan rata-rata keseluruhan siklus I yaitu 52\% sedangkan pada siklus II hasil belajar psikomotor siswa yaitu $83 \%$ berada pada kategori baik, pada pertemuan kedua yaitu 92\% berada pada kategori sangat baik, dan pertemuan ketiga yaitu sebesar 100\% berada pada kategori sangat baik. maka dapat 
R. Novioleta, N. Wedyawati, A. Kurniati | JPDP 6 (1) April 2020, 41-54

disimpulkan bahwa penilaian diperoleh hasil menjadi sebesar 98\% psikomotor siswa mengalami dengan kategori A (sangat baik), maka peningkatan yang sangat baik dari pada siklus II ini siswa sangat senang siklus I ke siklus II karena sudah mecapai kriteria sangat baik. Dengan rata-rata pada siklus I yaitu 52\% kategori C (cukup), untuk mendapatkan hasil yang sangat baik atau hasil yang memuaskan maka peneliti melanjutkan penilaian psikomotor siswa kelas IV SD Negeri 09 Nanga Tikan pada siklus ke II dan pada siklus II ini nilai psikomotor siswa mengalami peningkatan dengan nilai yang didapat yaitu dengan ratarata pada siklus II sebear 92\% kategori A (sangat baik) maka peningkatan rata-rata dari siklus I ke siklus II yaitu sebesar 40\%.

Respon siswa terhadap penggunaan model mind mapping pada siklus I ini angket respon siswa disebarkan pada hari Selasa, 13 Agustus 2019 diperoleh hasil sebesar 76\% dengan kategori B (baik) maka respon siswa terhadap penggunaan model mind mapping pada siklus I ini yaitu siswa senang terhadap penggunaan model mind mapping yang peneliti gunakandan pada siklus II angket respon siswa disebarkan pada hari Rabu, 21 Agustus 2019 terhadap penggunaan model mind mapping yang peneliti gunakan, maka dapat disimpulkan bahwa respon siswa terhadap penggunaan model mind mapping pada tema selalu berhemat energi subtema sumber energi dikelas IV SD Negeri 09 Nanga Tikan tahun pelajaran 2019/2020, yaitu siswa sangat senang pembelajaran dengan menggunakan model mind mapping yang peneliti terapkan.

Berdasarkan hasil wawancara guru bahwa pembelajaran menggunakan model mind mapping yang baru berlangsung cukup memuaskan karena siswa dapat belajar dengan lebih menyenangkan atau tidak membosankan dan dengan pembelajaran menggunakan model mind mapping siswa lebih kreatif. Dari wawancara yang telah dilakukan pada setiap akhir siklus I dan siklus II maka dapat disimpulkan bahwa guru wali kelas IV SDN 09 Nanga Tikan memiliki tanggapan atau respon yang baik terhadap model mind mapping yang diterapkan oleh peneliti pada tema 
R. Novioleta, N. Wedyawati, A. Kurniati | JPDP 6 (1) April 2020, 41-54

selalu berhemat energi subtema sumber energi.

\section{Simpulan}

Hasil observasi guru menggunakan model mind mapping siklus I pertemuan pertama sebesar $50 \%$, pada pertemuan kedua sebesar $60 \%$ dan pada pertemuan ketiga sebesar $80 \%$ dan siklus II pertemuan pertama adalah $100 \%$, pertemuan kedua $100 \%$ dan pertemuan ketiga sebesar 100\%. Hasil observasi aktivitas belajar siswa siklus I pertemuan pertama sebesar $50 \%$, pada pertemuan kedua sebesar $60 \%$ dan pada pertemuan ketiga sebesar $80 \%$ dan siklus II pertemuan pertama adalah $100 \%$, pertemuan kedua $100 \%$ dan pertemuan ketiga sebesar $100 \%$ maka hasil observasi guru dan siswa menggunakan model mind mapping sudah sangat baik.

Peningkatan hasil belajar kognitif menggunakan model mind mapping di kelas IV Sekolah Dasar Negeri 09 Nanga Tikan mengalami peningkatan sebesar 18,88\%. Berarti penelitian tindakan kelas dengan menggunakan model mind mapping berhasil dan berjalan dengan baik.
Peningkatan hasil belajar afektif di kelas IV SD Negeri 09 Nanga Tikan mengalami peningkatan dengan ratarata nilai $73 \%$ (baik) dan pada siklus II mengalami peningkatan yang signifikan menjadi 90\% (sangat baik) maka dapat disimpulkan penilaian afektif siswa mengalami peningkatan dan berhasil.

Peningkatan hasil belajar psikomotor di kelas IV SD Negeri 09 Nanga Tikan mengalami peningkatan dengan rata-rata nilai 52\% (cukup) pada siklus I dan siklus II mengalami peningkatan yang signifikan menjadi 92\% (sangat baik).

Respon siswa terhadap penggunaan model mind mapping menunjukan bahwa siswa sangat senang terhadap penggunaan model mind mapping. Hasil angket respon siswa siklus I dengan rata-rata nilai sebesar 76\% (senang) sedangkan siklus II mengalami peningkatan menjadi 98\% (sangat senang).

\section{Daftar Pustaka}

Amri, S. (2013). Pengembangan dan Model Pembelajaran Dalam Kurikulum 2013. Jakarta: PT Prestasi Pustakaraya. 
R. Novioleta, N. Wedyawati, A. Kurniati | JPDP 6 (1) April 2020, 41-54

Arikunto, S. dkk. (2015). Penelitian

Tindakan Kelas. Jakarta: Bumi Aksara.

Awang, I.S. (2017). Strategi

Pembelajaran, Tinjauan Umum

Bagi Pendidik. Sintang: STKIP

Persada Khatulistiwa.

Buzan, T. (2012). Buku Pintar Mind

Mapping. Jakarta: PT

Gramedia Pustaka Utama.

Kunandar. (2016). Langkah Mudah

Penelitian Tindakan Kelas

Sebagai Pengembangan

Profesi Guru. Jakarta: PT

Rajagrafindo Persada.

Majid. (2017). Penilaian Autentik

Proses dan Hasil Belajar.

Bandung: PT Remaja

Rosdakarya.

Shoimin, A. (2014). 68 Model

Pembelajaran Inovatif

Dalam Kurikulum 2013.

Yogyakarta: AR-RUZZ

MEDIA.

Slameto. (2015). Belajar dan Faktor-

Faktor yang

mempengaruhinya. Jakarta:

PT RINEKA CIPTA.

Sudjana, N. (2016). Penilaian Hasil Proses Belajar Mengajar. Bandung: PT Remaja Rosdakarya.

Sugiyono. (2016). Metode Penelitian Kuantitatif, Kualitatif, dan $R \& D$. Bandung:ALFABETA.

Susanto, S. (2016). “Metode Mind Mapping Untuk Meningkatkan Hasil Belajar IPS di Sekolah Dasar" Jurnal Pendidikan Guru Sekolah Dasar, Vol. I No. I Desember 2016.

Wedyawati, N, TDIR Makin. (2019). "Korelasi Tindakan Bullying Dengan Hasil Belajar Siswa Kelas Tinggi Sekolah Dasar Negeri 27 Pauh Desa Tahun pelajaran 2018/2019" Jurnal Ilmiah. Volume 10 No. 1, April 2019.

Zarkasih M, Wedyawati N, Sirhi S. (2016). "Pengaruh Model Stad Berbantu Media Gambar Terhadap hasil Belajar" Jurnal Pendidikan. Volume 2 No 2, April 2016. 